\title{
Exploring Work Values, Job Interest and Willingness to Apply On-Farm Occupation (Case Study: IPB University Students)
}

\author{
Sri Nur Elita Ermis ${ }^{1}$, Anggraini Sukmawati ${ }^{2}$, Farit M Afendi ${ }^{3}$ and Nor Siah Jaharuddin ${ }^{4}$ \\ \{elita_3010@apps.ipb.ac.id ${ }^{1}$, anggrainism@apps.ipb.ac.id², fmafendi@gmail.com ${ }^{3}$ \} \\ Management Department, Faculty of Economics and Management, IPB University, Babakan, Dramaga, \\ Bogor, West Java, 16680, Indonesia ${ }^{1,2}$ \\ Statistics Department, Faculty of Mathematic and Natural Science, IPB University, Babakan, Dramaga, \\ Bogor, West Java, 16680, Indonesia ${ }^{3}$
}

\begin{abstract}
Society's confidences of business are changing, and an increasing act of applicants pre-assess the societal and environmental execution of companies before choosing an employer. This study aims to analyze the differences in work values among students in IPB University to find out the type of work they enjoy so they can work in companies that are in accordance with their talents and interests. Descriptive statistical and PLS-SEM analysis were used to analyze the effect of work values to job interest and willingness to apply on-farm occupation.This paper used probability sampling with stratified random sampling technique and got 217 samples. There are five dominant values; ethics and integrity, responsibility, work conditions, opportunity of personal growth and use of ability and knowledge in work. Work values effects job interest positive significantly but work values is not affects willingness to apply significantly. Dominant factor of job interest is colleague/ family influence.
\end{abstract}

Keywords: Career choice, competency, generational Diversity, PLS-SEM, work ethics.

\section{Introduction}

Workforce demographic are changing (Armstrong \& Crombie 2000). While this may not be happening as fast as once predicted due to the poor economy, employee demographic are shifting toward a more diverse mix of employees (Murphy 2011). Currently students was born in 1998-2001 (Cran 2014) so they belong to Generation $Z$ will enter the workforce in the next 2-3 years. Their expectations of first job are realistic. Generation $\mathrm{Z}$ always try a new skills to get a meaningful work so they can enjoy the life (Mathew 2016). Barr (2017) found the characteristic of Generation $\mathrm{Z}$ are interest in technology, less brand loyalty, have more positive attitude, but less brand loyalty and are much less likely to choose farming as an occupation. 
There was a decrease in the percentage of work suitability with graduates at IPB University in 2016-2018 (IPB 2013). In 2016 there were 76.49 percent of graduates working in their fields, in 2017 there were 74.44 percent and in 2018 only 70.02 percent. Lin et al (2015) stated that in the global marketplace, the characteristics of college student have to manage in a different way so we can ensure that they are maximally productives to compete with the others.Previous research has shown that positive organizational performance is related to willingness to apply in the right job (Schwartz 1999).

The interest of job seekers can enhance by company. They will be more eager to apply if the job content is aligned with they interest (Crowder 2017). It would be better for both enterprises and applicants when the right candidate is chosen for the right job (Peterman et al 2016). Chi $\mathrm{H}$ et al (2018)in their study found that willingness to apply is effect by job interest, salary, and corporate image. They also state that the main factor of them is job interest.

As we know that Sustainable Development involves an economics outcomes, environmental, and a broad view of social. In order to boosting productivity, reducing staff turnover, and increasing staff morale and commitment, companyand employee values should be aligned. It also providing a suitable work-life balance and clearly demonstrating a concern for health and safety. Previous research found that $70 \%$ of staff said that in the past year, their productivity has increased because they were committed to the values of the company. In contrast, only $1 \%$ had improved their produvtivity because they were not committed to the values of the company. Survey also found that $80 \%$ of respondents who believed their company had strong ethics would recommend their organization. In comparison, among workers who feel their bosses lack integrity, only $20 \%$ would recommend the workplace to recruits (World Business Council for Sustainable Development).

To get the right candidate for the right job, company management needs to know work values that they looking for in the future (Wang 2019).Its also to may influence a job seeker's decision to apply a job (Johnson 2017).

The purposes of this research is to know how much interest students have in working in agriculture so company especially for on farm-occupation can find out their next talents. This study also analyze the differences in work values among students in IPB University to find out the type of work they enjoy so they can work in companies that are in accordance with their talents and interests, and the company can find out how much interest students have in working in agriculture. The work values of students in Indonesia needs to be studied in more depth. 


\section{Literature Review}

\subsection{Work Values}

The work values of employees are different in each generation (Lin 2015). The work values of employees should be understanding by organization because it will help organization in achieving higher performance. According to Crowder (2017), organizations need to understand the values of work held by each generation in the workplace. By knowing work values that form the basis of employee work behavior, organizations can build strength, be more cohesive, and will increase productivity. Work values can affect job satisfaction, performance, company loyalty and longevity and turnover. Research from Anantatmula \& Shrivastav (2012) shows that there are differences in attitudes, values and work ethics in each generation. Work behavior referred to in this study is the work behavior of employees, namely how people in the work environment can actualize themselves through work attitudes, including the enthusiasm and excitement of work based on the work values adopted.

Basic values include prestige, social, extrinsic, adn extrinsic (Schwart 1999). There are 10 work values according to Schwartz (1999), namely security, conformity, tradition, universalism, self direction, benevolence, power, hedonism, achievement, and stimulation. power, achievement, hedonism, stimulation, self direction, universalism, benevolence, tradition, conformity and security. Firdausy (2017) uses 5 aspects of work values, namely rewards, opportunities, organizaton, work and people. While Fahreza (2018) uses 6 aspects of work values, namely organization, compensation, work, teamwork, pride and performance. Ralston et al. (2017) in their research found that in collectivism values there were significant region differences change between the low and moderate development regions and also between the high and moderate development regions.

Research conducted in China and Taiwan conducted by Lin et al. (2015) found that there are differences in the values of work between the two countries. Available six work values are used, namely quality of life, dreams, wealth, not feeling confused at work, opportunities to continue study and promotion opportunities. Murphy (2011) uses 25 aspects of work values, which can be shown in Table 1. 
Table 1. Aspects of work values according to Murphy (2011)

\begin{tabular}{rlrl}
\hline No & \multicolumn{1}{c}{ Work Values } & No. & \multicolumn{1}{c}{ Work Values } \\
\hline 1 & Achievementat work & 14 & Permanent work \\
2 & Opportunities for promotion & 15 & Job Status \\
3 & Insurance, retirement, leave, vacation & 16 & Meaningful work \\
4 & Proud of working in a company & 17 & Opportunity to become a better \\
& & & person \\
5 & Contribution to the community & 18 & Interaction with the environment \\
6 & Flexible working hours & 19 & Compensation \\
7 & Co-workers & 20 & Recognition after doing a good job \\
8 & Respect & 21 & Responsibilities \\
9 & Feedback & 22 & Fair and caring boss \\
10 & Independence at work & 23 & Using abilities and knowledge at \\
& & & work \\
11 & Influence in organization & 24 & Working conditions, comfortable \\
& & & and clean \\
12 & Influence on the job & 25 & Ethics and integrity \\
13 & Interest in work & & \\
\hline
\end{tabular}

Table 1 shows 25 aspects of work values which will be used later in this study. Valickas (2017) in his research found that there are differences in values adopted by the baby boomers and Y generations. Baby boomers are the generation of workaholics while the $\mathrm{Y}$ generation prefers free time at work and wants to work in jobs that are meaningful and attractive to them.

\subsection{Job Interest}

The balanced theory of career management posits that both organizations and individuals have their respective responsibility in managing career of employees. This responsibility of career management becomes critical for HRM function as this function is responsible for the strategic HR practices in organization. The long term commitment in organizations would exist only if the job in question matches the career expectations of the individuals. The major challenge facing the industry today is high performers in the experience range of two and five years leaving their jobs or returning to schools for higher education so that their career ecpectations are met.

These individuals are in the age group 18 to 23 years. These are the Generation $\mathrm{Z}$ who have higher career expectations, always demand meaningful work, and seek for constructive feedback an positions of influence within their organizations (Mathew 2016). There are so many definition of job interest. Job interest refer to willingness, reachable dreams and career targets that an individual wishes to gain (Armstrong \& Crombie 2000). Career interest refers 
to the goalsof an employee. The review of spesific characteristics of Generation $\mathrm{Z}$ and their career interest thus points to need for organizations to have spesific HR practices that adresses this need.

Chaplin (1995) has three categorize of interest; first, interest is an ongoing attitude captivate someone's attention, so that make himself selective about the object of his interest. Second, interest is a feeling that states that an activity, job, or object is valuable or meaningful to individuals. Third, interest is a motivational state, or a set motivation, which guides behavior heading on one direction (certain target).

\subsection{Job Application Willingness}

The willingness to apply is the job seeker's desire to work in a certain business organization (Ehrhart \& Ziegert 2005). Chi (2008) found that a willingness to apply a job hev significant positive effects from job interest, salary, and corporate image. willingness to apply describes the job seeker's desire to work in a certain business organization (Ehrhart \& Ziegert 2005). Chi (2018) found that a willingness to apply for a job have significant positive effects from corporate image, salary, and job interest. Both salary and job interest will exert moderating effects on willingness to apply, and job interest has a stronger influence than salary. This appeal is a key to company competitiveness. If a company possesses strong attraction for talent, it will have a greater opportunity to select gifted employess.

Estimates show that the labour markets of agricultural graduates have not been able to absorb 25-50 per cent. According to annual economic reviews and reports by Central Bank of the Islamic (2014) Republic of Iran , during thye recent five years period of 2010-2014, almost 250,000 agricultural and veterinary science students have graduated from Iranian universities, whilst a far greater propotion of them were unemployed for employed in nonagricultural jobs. Thus, career trajectories are not a matter of matching required and possesses skills (Syharifzadeh 2017). It seems that agricultural colleges have failed to impart the necessary business and soft skills for graduate employment.

Workforce demographic are changing (Armstrong\& Crombie2000). While this may not be happening as fast as once predicted due to the poor economy, employee demographic are shifting toward a more diverse mix of employees (Murphy 2011). Currently students was born in 1998-2001 (Cran 2014) so they belong to Generation $Z$ will enter the workforce in the next 2-3 years. 


\section{Research Methodology}

\subsection{Types and Sources of Data}

Type of data that used in this study isprimary datawith questionnaire. Sources of data from this study were obtained from the official website of the Indonesian Statistics Center. In addition, researchers also use other secondary data such as books, articles, news, journals, and other scientific studies that are relevant to this research.

The data collection method used in this study is the distribution of questionnaires both directly and through google forms and literature studies. The questionnaire was distributed to respondents who were the samples in this study, namely undergraduate students at IPB University at agriculture and non agriculture faculties who will graduation on next year. To get sample for this study use stratified sampling techniquewith faculties as strata. Minimum sample that have to used is 150 (indicator $\mathrm{x}$ 5).This study got 217 samples from IPB University. It means that sample is more than minimum frequency.

\subsection{Data Processing and Analyzing Methods}

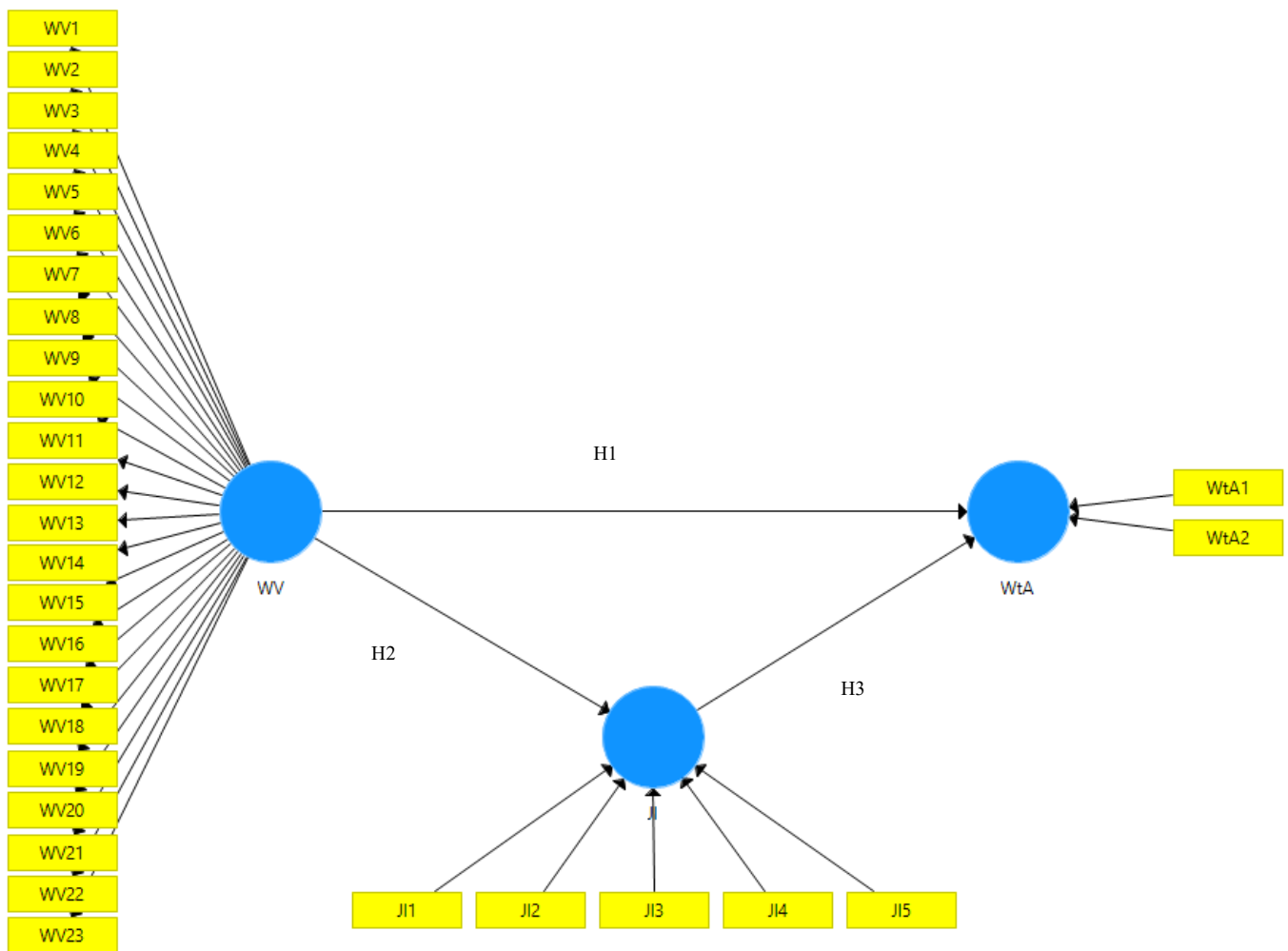

Figure 1. Model design 


\section{Hypothesis}

H1 : Work Values (WV) affects Willingness to Apply (WtA) students on farm occupation when choose a career.

H2 : Work Values (WV) affects Job Interest (JI) students on farm occupation when choose a career.

H3 : Job Interest (JI) affects Willingness to Apply (WtA) students on farm occupation when choose a career.

The data collection method uses online questionnaire which shared to IPB University. Identifying work values using 25 work values according to Murphy(2011). Identifying differences between IPB Universitystudent about values which they looking for at work. Analyze the effect of job interest and willingness to apply on-farm occupation using PLS-SEM (Partial Least Squares-Structural Equation Modelling) methodology.

Table 2. Dimensions of latent variables and indicators

\begin{tabular}{|c|c|c|c|}
\hline Variable & Definition & Indicator & Source \\
\hline $\begin{array}{l}\text { Work } \\
\text { (WV) }\end{array}$ & $\begin{array}{l}\text { Are expressions of } \\
\text { general values } \\
\text { within the context } \\
\text { of work that are } \\
\text { assessed and can } \\
\text { be ordered by } \\
\text { importance. Work } \\
\text { values are } \\
\text { underlying criteria } \\
\text { used to evaluate } \\
\text { aspects of work } \\
\text { and outcomes. }\end{array}$ & $\begin{array}{l}\text { 1. Benefits } \\
\text { 2. Proud to work } \\
\text { 3. Contribution to society } \\
\text { 4. Convenient hours of work } \\
\text { 5. Co-workers } \\
\text { 6. Esteem } \\
\text { 7. Feedback } \\
\text { 8. Independence } \\
\text { 9. Influence in the organization } \\
\text { 10. Influence in work } \\
\text { 11. Job interest } \\
\text { 12. Job security } \\
\text { 13. Job status } \\
\text { 14. Meaningful work } \\
\text { 15. Opportunity for personal growth } \\
\text { 16. Opportunity to interact with people } \\
\text { 17. Pay } \\
\text { 18. Recognition for doing a job } \\
\text { 19. Responsibility } \\
\text { 20. Supervisor, a fair and considerate } \\
\text { boss } \\
\text { 21. Use of ability and knowledge in } \\
\text { work } \\
\text { 22. Work conditions } \\
\text { 23. Ethics and integrity }\end{array}$ & $\begin{array}{l}\text { Murphy } \\
\text { (2011) }\end{array}$ \\
\hline Job Interest (JI) & $\begin{array}{l}\text { Is a motivational } \\
\text { state, or a set }\end{array}$ & 1 Motivational factors & $\begin{array}{l}\text { George } \\
\mathrm{V},\end{array}$ \\
\hline
\end{tabular}




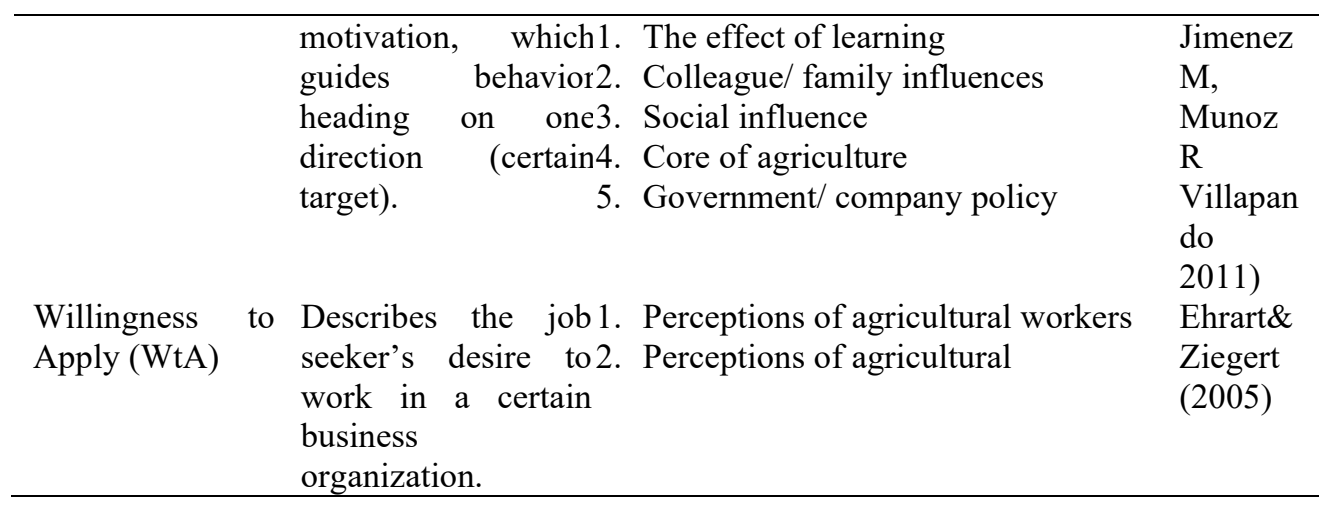

\section{Empirical Results}

\subsection{General Background}

IPB is the first agricultural higher that was formally established on 1 September 1963. The history of IPB began from the establishment of the Faculty of Agricultural Science, University of Indonesia in Bogor. The faculty establishment was the origin of IPB and $t$ the same time marked a new phase of agricultural higer education in Indonesia. Bung Karno (1952) said that the food problem can be solved by experts. Bung Karno did not take a shortcut to solvethe problem of that time by importing food, but by increasing the role of agricultural higher education institution to educate young people so that they would have the skill to build the farm and arouse people's awareness of the importance of food. One of the visionary thoughts that can be learned from his speech was the need for long-term planning in agricultural development. At the beginning IPB has four faculties but now IPB has 11 faculties.

\subsection{Sample Characteristics}

This study used description to analyze data. The description of the sample is as follows. In the aspect of gender, the majority were woman (66 per cent); in the aspect of age, the majority were under 25 (included); in theaspect of family backround, the majority were from non-agriculture background (73 per cent); in the aspect of occupational ranking, the majority were said that lecturer is the most prestigious work (mean $=7.34)$ and farmer is on sixth $($ mean $=6.29)$.

\subsection{Occupational Ranking}

In this context, this study shows the most prestigious occupation according to final year students as respondents. Therefore, it will be influence their career choice. The result shows the most prestigious work according to IPB students is university lecturer, the second is agriculture lecture, and the 
third is accountant. While farmer is ranked number six. It means that farmer belong to the rather prestigious category.

\subsection{SEM-PLS Analysis}

This study also used SEM-PLS to analyze the effect of work values to willingness to apply on-farm occupation with job interest as moderating variable. Work values is reflected by 23 indicators. Each indicator are asked to respondents through questionnaire with five-scale-Likert. There are two models in structural equation modelling, inner and outer model. Models of this study are evaluated using SmartPLS 3.0 with the results below.

\section{Outer Model Evaluation}

Evaluation of the outer model can be used to see how the manifest variable shows the latent variables to bemeasured. In this evaluation the are 3 types of tests, convergent validity, discriminant validity, and composite reability.

\section{a) Convergent Validity}

Convergent validity was assessed based on the correlation between item scores and construct scores calculated with PLS. The item will be categorized valid if the loading factor is 0.70 and above. Therefor, indicators with loading factors less than 0.70 will be erased from the model. The first calculation before the elimination of unvalid indicators can be seen in attachment 1 .

The are 30 indicators and 3 latent variables in the model. After calculating PLS Algorithm using SmartPLS 3.0, there are 11 indicators (Indonesia) categorized as unvalid indicators because the loading factor is less than 0.7 . Revised of outer loading shows the outer loadings after elimination of unvalid indicators that all indicators are valid because all of the loading factor are more than 0.7 .

\section{b) Discriminat Validity}

Discriminant validity is an analysis to see whether indicators can reflect latent variables or not. This analysis can be known based on AVE (Average Variance Extracted) Rate of each variables. AVE rate of each variables must be higher than 0.5. AVE rate of each latent variables is shown in Table 3.

Table 3. Average Varians Extracted (AVE) Rate

\begin{tabular}{lll}
\hline Variable & AVE & Discriminant Validity \\
\hline WV & 0.605 & Valid \\
Mediating Effect & 1.000 & Valid \\
\hline
\end{tabular}


Table 3 shows that the AVE rate of all latent variables are above 0.5. This means that the AVE rate of all variables are good and all latent variables considered valid.

\section{c) Composite Reability}

In addition to construct validity test, construct reability tests also needed and was measured by composite reability value of each latent variables is above 0.70 . Table 4 shows composite reability values from this model. Table 4 shows that the Composite Reability of all latent variables are $>0.70$ so that they are reliable.

Table 4. Composite Reability

\begin{tabular}{lcl}
\hline Variable & Composite Reability & Reliability \\
\hline WV & 0.958 & Reliable \\
Mediating Effect & 1.000 & Reliable \\
\hline
\end{tabular}

\section{Inner Model Evaluation}

This analysis is used to test the hypotesis by using bootsrap to see the value of T-Value and path coefficient. Through this test, we can see if exogenous latent variables significantly affects endogeneous latent variables or not. The hypotesis can be accepted if the original sample value is more than $>p$ value. The original sample is served to see the relationship between latent variables (positive or negative). Figure 2 shows the affect from each latent variables.

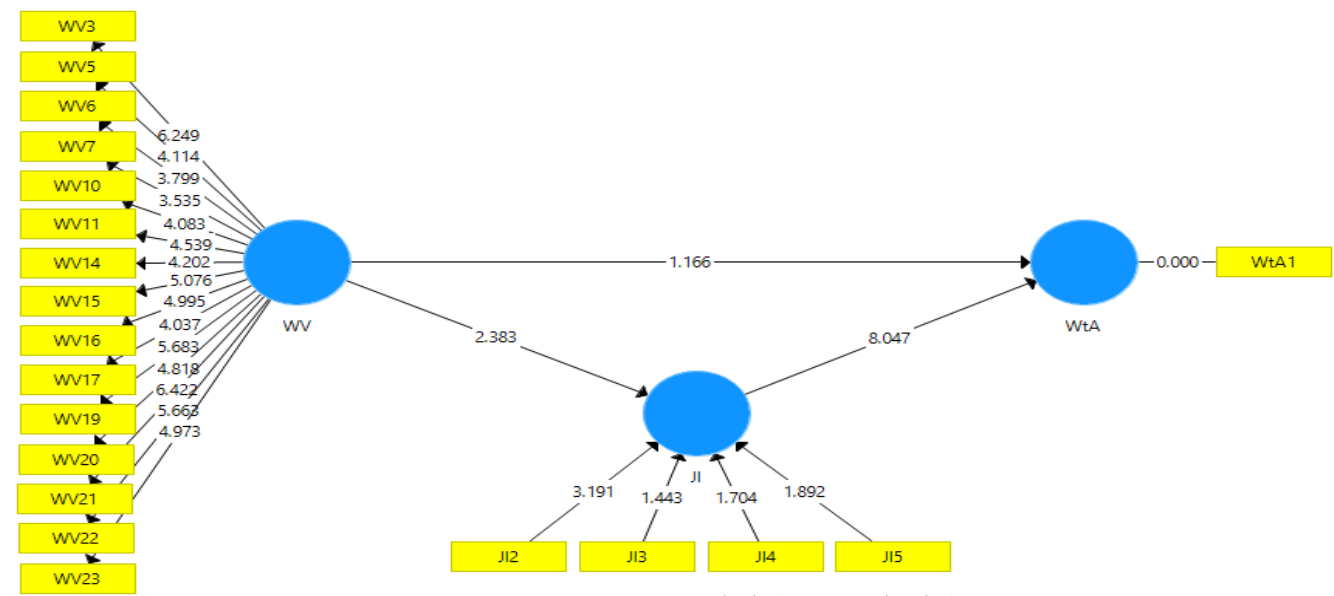

Figure 2. Inner Model (T-statistic) 
Table 5. Result of Path Coefficient

\begin{tabular}{lllll}
\hline Variables & $\begin{array}{l}\text { Original } \\
\text { Sample }\end{array}$ & P Values & Hypotesis \\
\hline Work values $\rightarrow$ Willingness & to & -0.095 & 1.166 & Not Significant \\
Apply & & 0.206 & 0.206 & Significant \\
$\begin{array}{l}\text { Work Values } \rightarrow \text { Job Interest } \\
\text { Job Interest } \rightarrow \text { Willingness }\end{array}$ to & 0.488 & 0.488 & Significant \\
$\begin{array}{l}\text { Apply } \\
\text { Mediating Effect } \rightarrow \text { WtA }\end{array}$ & 0.100 & 2.285 & Significant \\
\hline
\end{tabular}

The result from bootsraping process of each variables for this study is shown in Table 5. Table 5 shows that work values have a significant positive influence on job interest and job interest has a significant positive influence on willingness to apply. Work values not effect willingness to apply significantly but job interest as mediating variable effect willingness to apply significantly (pure mediating).

\section{Conclusions}

Work values towards job interest significantly in IPB. By sample analysis, dominant work values are ethics and integrity, responsibility, work conditions, comfortable and clean, opportunity of personal growth, use of ability and knowledge in work.

The study also found that willingness to apply is influenced by job interest. From models, we know that students only willing to apply a job if they are interested.

Therefore, from the mediating effect analysis, we know that job interest as mediating variable effect willingness to apply significantly (pure mediating). In other words, Indonesian students take job interest into consideration.

In the aspect of job interest, colleague/ family influence is dominant factor. There is problem because effect of learning is not significant. University have to make sure that students has knowledge of agriculture careers more to increase their interest (Sharifzadeh 2017). Lack of knowledge means they don't understand the full breadth of job types available to them. Therefore, its need to prove that an agriculture career can give them all the things they are looking for in a career.

Acknowledgments. Our thank you to the International Collaboration Office (ICO) IPB University, and Department of Management, IPB University for the support and collaboration in the Research Attachment Program. 


\section{References}

[1] Akerlof, G. A., \& Shiller, ArmstrongPI, Crombie G. 2000. Compromises in adolescents occupational aspirations and expectations from grades 8 to 10 . JVB. 56(1) 82-98.

[2] Central Statistics Agency of Indonesia. 2019. [internet]. [referenced 2019 October 29). Available from: bps.go.id

[3] Chaplin JP. 1995. Kamus lengkap psikologi (Kartini \& Kartono, Penerj). Jakarta: Grafindo Persada

[4] Chi H, Yeh H, Guo T. 2018. Salary or job interest? How salary and job interest moderates the willingness to aplly for a job. APJBA. 10(1) doi:10.1108/APJBA-09-2017-0086

[5] Cran C. 2014. 101 Tips Mengelola Generasi X, Y, \& Zoomer di Tempat Kerja. Jakarta: Kepustakaan Populer Gramedia.

[6] Crowder RBB. 2017. Work motivation theory : Identifying-multi generational values in the workplace[disertasi]. Minneapolis (MN):Walden University.

[7] Department of Statistics Malaysia. 2019. Key Statistics Of Labour Force In Malaysia.

[8] IPB. 2013. https://ipb.ac.id/news/index/2013/06/cooperation-of-ipb-andupm-malaysia/ea57c6d373d26b5be56e3641b183621d

[9] Johnson MH. 2017. Multi-generational workforce understanding generational diferences [disertasi]. Nashville (TN):Trevecca Nazarene University

[10] Ministry of Foreign Affairs of the Republic of Indonesia (Ministry of Foreign Affairs). 2019. ASEAN Economic Community (AEC) [internet]. [referenced 2019 Oktober 29]. Available in: kemenlu.go.id

[11] Lin JW, Shen PF, Hsu YS. 2015. Effects of employee's work values and organizational management on corporate performance for chinese and taiwanese construction enterprises. Journal Sustainability. 7.doi: $10.3390 / \mathrm{su} 71215852$

[12] Mathew A. 2016. Career expectations and organizational commitment of millennial industry - An SHRM Perspective. IJBM 4(1) 
[13] Murphy MM. 2011. Exploring generational differences among millennials, Gen Xers and Baby Boomers: work values, manager behavior expectations, and the impact of manager behaviors on work engagement [disertasi]. Los Angeles (CA): Alliant International University.

[14] Orborn Barr. 2017. Farmers of tomorrow: Generation Z's Future in Agriculture.

[15] Peterman K, Allen RK, Knezek G, Christense R, Wood TT. 2016. Measuring Student Career Interest within the Context of TechnologyEnhanced STEM Projects: A Cross-Project Comparison Study Based on the Career Interest Questionnaire. JSED. doi: 10.1007/s10956-016-9617-5

[16] Pinilih M, Yulianti H. 2016. Perbandingan Tenaga Kerja Indonesia dengan Tenaga Kerja ASEAN. UNSOED. JP. 9(1)

[17] Ralston DA, Egri Cp, Karam CM, Li y, Fu pp. 2017. Changes in work values across the regions of China. USA. doi:10.1007/s10490-017-9519-y

[18] Schwartz SH. 1999. Basic individual values, work values, and the meaning of work. Journal of Applied Psycology. 48(1).doi:10.1080/026999499377664

[19] Sharifzadeh M, Mohammadinezhad S. 2017. Agricultural entrepreneurship orientation: is academic training a missing link?. 59(7/8) 856-870. doi.10.1108/ET-10-2016-0156

[20] [SHRM] Society for Human Resource Management. 2009. The Multigenerational Workforce: Opportunity for Competitive Success. SHRM Research Management. 1:2-3

[21] Strauss W, Howe N. 2007. The Next 20 Years: How Consumer and Workforce Attitudes Will Evolve. $H B R$

[22] Wang J, Lee MH. 2019. Based on Work Value to Discuss the Effect of Collect Student's Corporate Internship on teh Employability. RDCSIS. 64(2536). doi.org/10.33788/rcis.64.2

[23] World Business Council for Sustainable Development. 2004. Driving Success Human Resources and Sustainable Development. 